\title{
Toll-Like Receptors and Agonist Responses in the Developing Fetal Sheep Lung
}

\author{
NOAH H. HILLMAN, TIMOTHY J.M. MOSS, ILIAS NITSOS, BORIS W. KRAMER, CINDY J. BACHURSKI, \\ MACHIKO IKEGAMI, ALAN H. JOBE, AND SUHAS G. KALLAPUR
}

Cincinnati Children's Hospital Medical Center [N.H.H., C.J.B., M.I., A.H.J., S.G.K.], University of Cincinnati, Cincinnati, Ohio 45229; School of Women's and Infants' Health [T.J.M.M., I.N.], The University of Western Australia, Perth, Australia; Department of Pediatrics [B.W.K.], Academisch Ziekenhuis Maastricht, 6202 AZ Maastricht, The Netherlands

\begin{abstract}
Toll-like receptors (TLRs) are pattern recognition molecules that initiate innate immune responses. Intra-amniotic exposure of fetal sheep to pro-inflammatory stimuli causes pulmonary inflammation and induced lung maturation. We examined TLR ontogeny and fetal lung responsiveness to three different TLR agonists. We cloned ovine TLRs 2, 3, and 4 and found 83-88\% homology between these ovine and human TLRs. Lung TLR2 and 4 mRNAs increased throughout late gestation to $50 \%$ of adult level in the term newborn lamb. Doses of $10 \mathrm{mg}$ of PAMCysK 4 (TLR2 agonist), poly I:C dsRNA (TLR3 agonist), or E. coli O55:B5 lipopoysaccharide (LPS) (TLR4 agonist) were given by intra-amniotic injection $2 \mathrm{~d}$ or $7 \mathrm{~d}$ before operative delivery of preterm lambs at $123 \mathrm{~d}(n=$ 4-7/group). The TLR4 agonist induced lung inflammation and maturation, whereas the TLR2 agonist gave less consistent responses. Intra-amniotic LPS increased TLR2 mRNA expression primarily in the inflammatory cells and TLR4 mRNA diffusely in multiple cell types. The TLR3 agonist had no effects, and TLR3 mRNA in the fetal lung did not change after LPS exposure. We conclude that TLR2 and TLR4 mRNAs increase through gestation and expression of TLR2 and TLR4 are induced by LPS in the fetal sheep lung. (Pediatr Res 63: 388-393, 2008)
\end{abstract}

$\mathrm{C}$ horioamnionitis is the most common risk factor associated with extremely premature births (1). Clinically, fetal exposure to chorioamnionitis is associated with early lung maturation and increased survival $(2,3)$, but also with an increased risk for bronchopulmonary dysplasia in some clinical studies (4). Chorioamnionitis at early gestation ages is usually caused by organisms with relatively low pathogenicity, such as Ureaplasma, Mycoplasma, and Gardenella species (1). The ascending infection may be chronic and not apparent clinically (5). This chronic fetal exposure to organisms/infection can induce fetal responses that range from minimal systemic fetal inflammatory responses to sepsis (3). How the fetus recognizes and responds to infection remains essentially unstudied.

Toll-like receptors (TLR) are a family of extracellular and intracellular receptors that recognize specific pathogenassociated molecular motifs (6). TLRs are expressed by both

Received July 23, 2007; accepted November 20, 2007.

Correspondence: Suhas Kallapur, M.D., Cincinnati Children's Hospital Medical Center, Division of Pulmonary Biology, 3333 Burnet Avenue, Cincinnati, OH 45229-3039; e-mail: Suhas.kallapur@cchmc.org

Supported by NIH HL-65397 (AHJ), K08 award HL-70711 (SGK), a NIH training grant HD07541 (NHH), a NHMRC RD Wright Career Development Award (TJMM).

DOI: 10.1203/PDR.0b013e3181647b3a immune and nonimmune cells and initiate the innate immune inflammatory signaling cascade. TLR expression can be induced by agonists, cytokines, and environmental stresses to the mature immune system (7). The fetus is generally thought to be immune naive and to have immature and poorly responsive immune signaling (8). However, the fetus can mount innate inflammatory responses to chorioamnionitis in humans and sheep (9). TLR2 and TLR4 receptors were detected in fetal mouse lung (embryonic day 14-15) and in human chorioamnion $(10,11)$. The fetal expression of TLRs, localization, and response to agonists, which mimic chorioamnionitis, remain largely unstudied.

We developed a model of chorioamnionitis, lung injury, and early lung maturation in fetal sheep $(12,13)$. Exposure of fetal lambs to intra-amniotic injections of $E$. coli lipopolysaccharide (LPS), Interleukin 1 (IL-1) $\alpha$, A. actimomycetumcomitans LPS, and live Ureaplasma parvum all initially cause lung inflammation followed by an induced maturation phenotype (14-16). This early lung maturation is characterized by improved lung mechanics and gas exchange, and increased surfactant, but also includes indicators of injury. Intraamniotic injection of LPS, the TLR4 agonist, interferes with alveolar septation (17), and causes more injury to the developing pulmonary microvasculature than does IL-1 (16). LPS also causes more inflammation than does chronic colonization with live Ureaplasma, a TLR2 plus TLR6 agonist, but both exposures induce lung maturation (14). Therefore, the fetal responses to TLR signaling seem to differ for different agonists.

The innate immune system is immature in the fetus (8). Fetal blood monocytes produce less hydrogen peroxide on exposure to a panel of TLR agonists than do monocytes from adult sheep (18). The fetal sheep lung responds to intra-amniotic injections of LPS as early as $60 \mathrm{~d}$ gestation (40\% term) (19), demonstrating that TLR4 receptors can signal inflammation early in fetal lung development. However, little is known about the fetal response to exposures with other specific TLR agonists or if TLRs are induced by inflammation in the fetus. To study the developmental changes in TLRs, we cloned and characterized the mRNA expression of TLR2, TLR3, and TLR4 in fetal sheep lung. We also evaluated fetal inflammatory and lung maturation responses to TLR2, 3, and 4 agonists

Abbreviations: BALF, bronchoalveolar alveolar lavage fluid; LPS, lipopolysaccharide; Sat PC, saturated phosphatidylcholine; TLR, toll-like receptors 
Table 1. RNase protection probes for ovine toll-like receptors

\begin{tabular}{|c|c|c|c|}
\hline Insert cDNA & Cloning strategy & Antisense RNA probe & $\begin{array}{c}\text { Protected fragment } \\
\text { size, nt }\end{array}$ \\
\hline TLR2 & $\begin{array}{l}334 \text { bp fragment, nucleotides (2156-2489) } \\
\text { cloned in pGEM-T (pGEMT-sTLR2.2) }\end{array}$ & $\begin{array}{l}\text { pGEMT-sTLR } 2.2 \text { cut with Msl 1, } \\
\text { T7 RNA polymerase }\end{array}$ & 173 \\
\hline TLR3 & $\begin{array}{l}749 \text { bp fragment, nucleotides (1969-2717) } \\
\text { cloned in pGEM-T (pGEMT-sTLR3.3) }\end{array}$ & $\begin{array}{l}\text { pGEMT-sTLR3.3 cut with Mfe } 1 \text {, } \\
\text { SP6 RNA polymerase }\end{array}$ & 194 \\
\hline TLR4 & $\begin{array}{l}514 \text { bp fragment, nucleotides (1271-1785) } \\
\text { cloned in pGEM-T (pGEMT-sTLR4.2.4) }\end{array}$ & $\begin{array}{l}\text { pGEMT-sTLR4.2.4 cut with BstY 1, } \\
\text { T7 RNA polymerase }\end{array}$ & 142 \\
\hline
\end{tabular}

given by intra-amniotic injection, and the effects of the agonist exposures on TLR mRNA expression in the fetal lung.

\section{METHODS}

Animals. The animal studies were performed in Western Australia using time-mated Merino ewes with singleton gestations. The studies were approved by the animal care and use committees of the Department of Agriculture in Western Australia and Cincinnati Children's Hospital Medical Center. Measurements for the ontogeny of TLR2, 3, and 4 mRNA were made using lung tissue from unmanipulated fetuses delivered at 108, 118, 123, 130, 145 d gestational age (term $150 \mathrm{~d}$ gestational age), newborn lambs, and from adult ewes. For testing TLR responses, intra-amniotic injections were given using ultrasound guidance (12). Each ewe received intra-amniotic injection of either (1) $10 \mathrm{mg}$ PAMCysK $_{4}$ in $2 \mathrm{~mL}$ saline (EMC Microcollections, Tubingen, Germany), (2) $10 \mathrm{mg}$ poly I:C dsRNA (InvivoGen, San Diego, CA) in $2 \mathrm{~mL}$ saline, (3) $10 \mathrm{mg}$ E. coli LPS (055:B5; Sigma Chemical Co., St. Louis) in saline, or $2 \mathrm{~mL}$ saline (controls). Fetal sheep develop lung inflammation to intra-amniotic doses of $0.1 \mathrm{mg}$ LPS and lung maturation occurs consistently after $1-4 \mathrm{mg}$ doses of $E$. coli endotoxin or $100 \mu \mathrm{g}$ IL- $1 \alpha$ $(12,13,20)$. Therefore, the $10 \mathrm{mg}$ dose of the TLR agonists was selected as a high dose to test for responsiveness. The ewes were killed by penetrating captive bolt followed by immediate operative delivery of the lambs at $123 \mathrm{~d}$ gestational age. The lambs then were given a lethal dose of $100 \mathrm{mg} / \mathrm{kg}$ pentobarbital. Birth weights and cord blood gases were recorded.

Lung processing. The fetal chest was opened and static lung compliance was measured by determining lung gas volumes on inflation of the lung to 40 $\mathrm{cm}_{2} \mathrm{O}$ pressure (12). The lungs were weighed, and the left lung was used for a bronchoalveolar lavage (BAL) that was repeated three times using cold saline (13). A cell pellet from the BAL fluid (BALF) was used for a cell count determined by hemocytometer using trypan blue exclusion to identify live cells. BALF was used for cytospin and the slides were stained with Leishman's stain (BDH, Poole, UK) for differential cell counts. Pieces of the right lower lobe of the lung were snap frozen for RNA analysis. The right upper lobe of the lung was inflation fixed in $10 \%$ buffered formalin at $30 \mathrm{~cm} \mathrm{H}_{2} \mathrm{O}(17)$.

Saturated phosphatidylcholine. Lipids were extracted from the BALF with chloroform-methanol. Saturated phosphatidylcholine (Sat PC) was isolated by neutral alumina column chromatography after exposure to osmium tetroxide and was quantified with a phosphorous assay (12).

Ovine TLRs. Ovine TLR2, 3, and 4 were cloned into pGEM-T by PCR using primers designed from homologous regions of mouse, bovine, and human TLR cDNAs. Identity of all clones was confirmed by sequencing and compared with published TLR sequences (NCBI accession: TLR2 NM1048231, TLR3 NM1008664, TLR4 AM231300) (Table 1).

RNase protection assays. Total RNA was isolated using a modified Chomzynski method (21), and $10 \mu \mathrm{g}$ of total lung RNA was used for RNase protection assays using sheep-specific riboprobes for IL-1 $\beta$, IL-6, IL-8, TLR2, TLR3, TLR4, and L32 (9). Solution hybridization was performed in $80 \%$ deionized formamide, $0.4 \mathrm{M} \mathrm{NaCl}, 2 \mathrm{mM}$ EDTA, and $0.04 \mathrm{M}$ PIPES, $\mathrm{pH}$ 6.6 , using a molar excess of $\left[\alpha-{ }^{32} \mathrm{P}\right] \mathrm{UTP}-$ labeled probes for $16 \mathrm{~h}$ at $56^{\circ} \mathrm{C}$. Single-stranded RNA was digested with RNase A/T1 (Pharmingen, San Diego, CA). RNase was inactivated, and the protected RNA was precipitated using RNAse inactivation buffer (Ambion, Austin, TX). L32 (ribosomal protein mRNA) was used as an internal control for loading (9). The protected fragments were resolved on $6 \%$ polyacrylamide $8 \mathrm{M}$ urea gels, visualized by autoradiography, and quantified on a PhosphorImager using ImageQuant version 1.2 software (Molecular Dynamics, Sunnyvale, CA).

In Situ hybridization. Formalin fixed right upper lobe was processed and embedded in paraffin, $5 \mu \mathrm{m}$ thick sections were used for in situ hybridization with ${ }^{35}$ S-labeled probes as previously described (22). The plasmids sTLR4.2.4, and sTLR2.2 were digested with NotI for antisense probe (T7 polymerase; Promega) and with $\mathrm{NcoI}$ for sense probe (SP6 polymerase; Promega) synthesis. For hybridization, the sense and the antisense probes were diluted in hybridization buffer to a final concentration of $4.7 \times 10^{4}$ $\mathrm{cpm} / \mu \mathrm{L}$ and incubated at $54^{\circ} \mathrm{C}$ for TLR2 and $48^{\circ} \mathrm{C}$ for TLR4. After hybridization, the TLR4 probe sections were washed with a buffer containing $50 \%$ formamide, $5 \times \mathrm{SSC}(300 \mathrm{mM} \mathrm{NaCl}, 30 \mathrm{mM}$ sodium citrate, $\mathrm{pH} 7.0)$ and 20 $\mathrm{mM}$ dithiothreitol (DTT) for $60 \mathrm{~min}$ at $50^{\circ} \mathrm{C}$ was used . Sections with TLR 2 probe were washed with a buffer containing $50 \%$ formamide, $2 \times$ SSC and $10 \mathrm{mM}$ DTT for $30 \mathrm{~min}$ at $65^{\circ} \mathrm{C}$ was used. The sections were treated with RNase A/T1 to reduce nonspecific binding and subsequently washed in a descending series of SSC solutions ending in a $15 \mathrm{~min}$ wash at room temperature in $0.1 \times \mathrm{SSC} / 1 \mathrm{mM}$ DTT. Tissue sections were photographed under dark-field illumination and then counterstained with hematoxylin for morphologic analysis.

Statistics. All values are expressed as mean $\pm \mathrm{SE}$, and comparisons between treated animals and controls were made with two-tailed Mann-Whitney nonparametric test, Welch $t$ tests, or two-way Kruskal-Wallis nonparametric analysis of variance as appropriate. Significance was accepted at $p<0.05$.

\section{RESULTS}

Ontogeny and localization of lung TLR2 and TLR4 expression. The homology between the cloned regions of ovine TLRs 2, 3, and 4 and human TLRs was $83-85 \%$. Ovine TLR2, 3, and 4 were detected by RNase protection assay at $108 \mathrm{~d}$ gestation (Fig. 1). The mRNA for TLR2 increased with

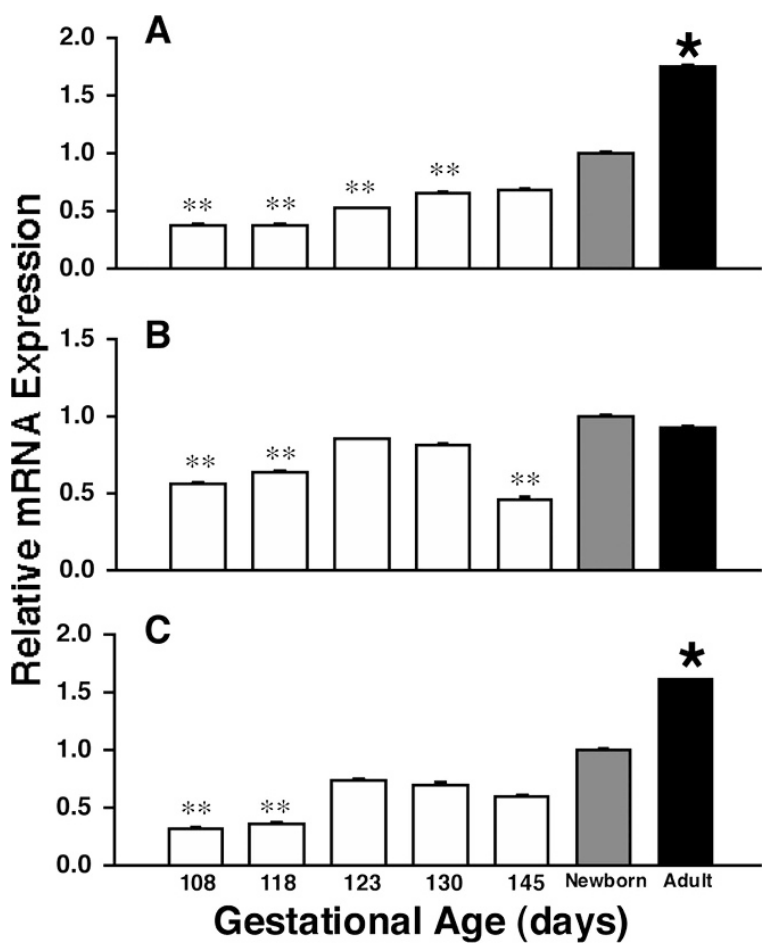

Figure 1. Toll-like receptor (TLR) mRNA ontogeny in sheep lung. (A) TLR2 mRNA, $(B)$ TLR3 mRNA, and (C) TLR4 mRNA were quantified by RNase Protection Assay. TLR mRNAs were initially normalized to L32 mRNA (loading control) and then expressed relative to the value of 1 for newbornlung. ( $n=4-5$ lambs per gestational age, $n=6$ for newborn and adult). $(* p<0.05$ versus all other groups, $* * p<0.05$ versus newborn). 


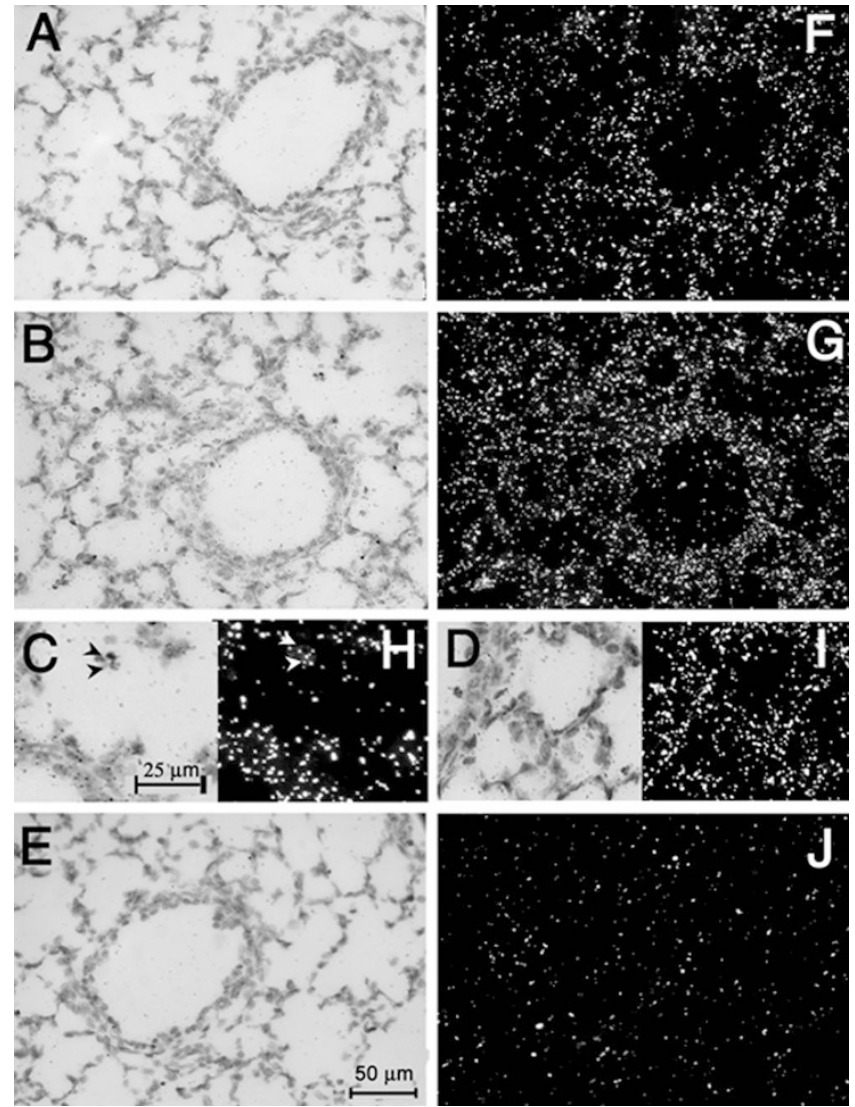

Figure 2. Expression of TLR4 mRNA in fetal sheep lung. In situ hybridization was performed with $\left[{ }^{35} \mathrm{~S}\right]$-labeled sheep TLR4 probe on lung sections from saline and LPS-exposed lambs. Bright field images $(A-E)$ and dark field images $(F-J) .(A, F)$ Control lung section shows expression of TLR4 as detected by the antisense probe; $(B, G) 2 \mathrm{~d}$ after intra-amniotic LPS, the antisense probe more heavily labels the lung tissue in a diffuse pattern $(D, I)$; $(C, H)$ minimal increase seen in inflammatory cells (arrows). $(E, J)$ Control tissue showed minimal background labeling with sense probe.

gestational age from $20 \%$ of adult values at $108 \mathrm{~d}$ gestation to $50 \%$ of the adult level in the term newborn. The changes in TLR4 mRNA with gestational age were similar in magnitude to TLR2. The increases with gestation were less striking for TLR3. TLR4 mRNA was uniformly distributed throughout the lung parenchyma, in epithelium, mesenchyme, and inflammatory cells (Fig. $2 F, H$ ). This nonfocal distribution was more intense $2 \mathrm{~d}$ after intra-amniotic LPS (Fig. $2 G, I$ ). In contrast, the TLR2 mRNA was expressed at low levels in the parenchyma of control lung (Fig. 3A, D). The predominant TLR2 mRNA expression was in the inflammatory cells $2 \mathrm{~d}$ after intra-amniotic LPS exposure (Fig. $3 B, E$, insets).

Description of lambs exposed to intra-amniotic TLR agonists. All lambs survived the intra-amniotic injections of the TLR agonists, and at delivery 2 or $7 \mathrm{~d}$ after treatment, cord blood $\mathrm{pH}$ values and birth weights were similar (Table 2). None of the ewes went into preterm labor.

Inflammatory and cytokine responses to TLR agonists. Inflammatory cells in BALF were increased 2 and $7 \mathrm{~d}$ after intra-amniotic injection of E. coli LPS and PAMCysK 4 , but not after poly I:C dsRNA (Fig. $4 A, B$ ). Cell numbers were about an order of magnitude higher for LPS than for PAM$\mathrm{CysK}_{4}$. The $10 \mathrm{mg}$ dose of poly I:C dsRNA did not increase

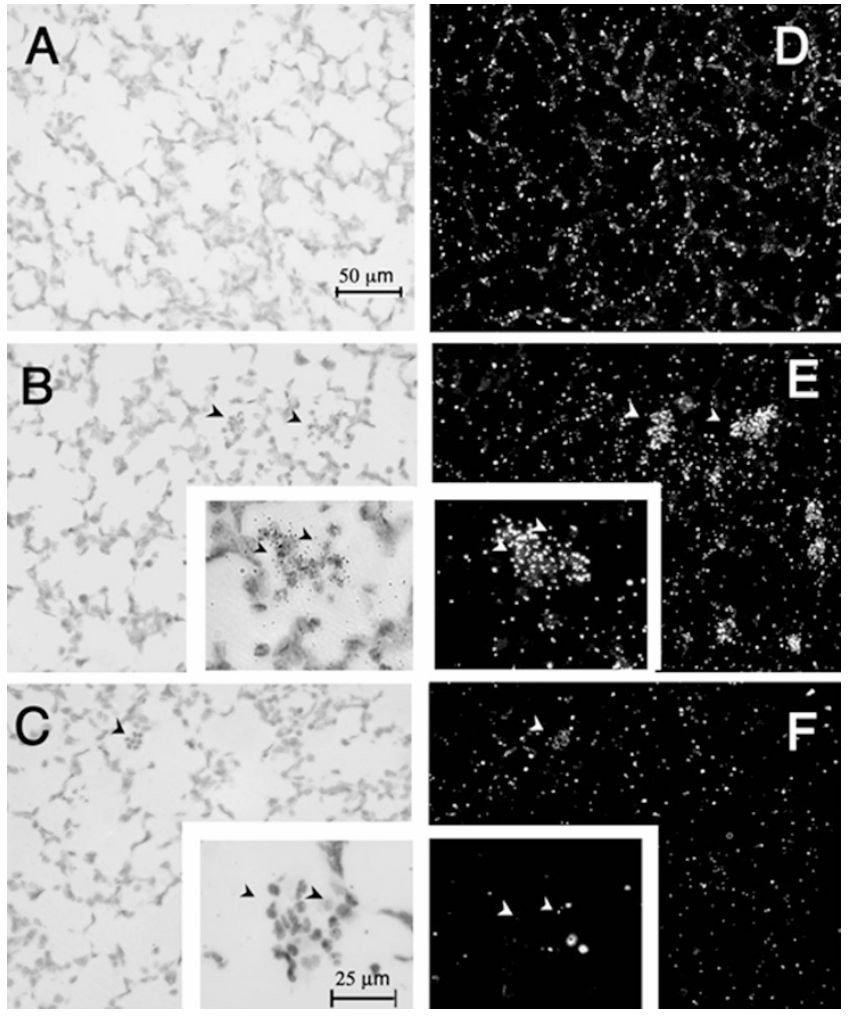

Figure 3. Expression of TLR2 mRNA in fetal sheep lung. In situ hybridization was performed with $\left[{ }^{35} \mathrm{~S}\right]$-labeled sheep TLR2 probe on lung sections from saline and LPS-exposed lambs. Bright field images $(A-C)$ and dark field images $(D-F)$. $(A, D)$ Control lung tissue reacted with antisense TLR2 probe diffusely throughout the parenchyma; $(B, E) 2 \mathrm{~d}$ after exposure to intraamniotic LPS the antisense probe was increased in inflammatory cells (arrowheads). The inset shows labeling of clusters of inflammatory cells; $(C, F)$ $2 \mathrm{~d}$ after exposure to intra-amniotic LPS, the sense probe showed minimal nonspecific binding in parenchyma and inflammatory cells, (inset $C, F$ ).

inflammatory cells at 2 or $7 \mathrm{~d}$. The expression of proinflammatory cytokine mRNA for IL- $1 \beta$, IL- 6 , and IL-8 were increased in the fetal lung tissue at $2 \mathrm{~d}$ by LPS exposure, but not by PAMCysK $\mathrm{P}_{4}$ or Poly I:C dsRNA (Fig. $4 C$ ). The proinflammatory cytokine mRNAs were similar to control values at $7 \mathrm{~d}$ for all groups (data not shown).

Induced lung maturation. LPS-induced early lung maturation at $7 \mathrm{~d}$, as demonstrated by increased lung gas volumes at $40 \mathrm{~cm} \mathrm{H}_{2} \mathrm{O}$ and increased Sat PC in BALF (Fig. 5). For the group comparisons, the lung gas volume of $14.9 \pm 3.6 \mathrm{~mL} / \mathrm{kg}$ for $\mathrm{PAMCysK}_{4}$ was not significantly different $(p=0.07)$ from

Table 2. Description of animals that received intra-amniotic injections

\begin{tabular}{lcccc}
\hline $\begin{array}{c}\text { Intra-amniotic } \\
\text { treatment* }\end{array}$ & $\mathrm{N}$ & $\begin{array}{c}\text { Interval to delivery at } \\
123 \pm 1 \mathrm{GA}(\mathrm{d})\end{array}$ & $\begin{array}{c}\text { Body } \\
\text { weight }(\mathrm{kg})\end{array}$ & $\begin{array}{c}\text { Cord } \\
\text { blood } \mathrm{pH}\end{array}$ \\
\hline Saline & 7 & 2 or 7 & $2.8 \pm 0.2$ & $7.22 \pm 0.04$ \\
PAM & 4 & 2 & $2.5 \pm 0.1$ & $7.26 \pm 0.04$ \\
PAM & 7 & 7 & $2.4 \pm 0.2$ & $7.29 \pm 0.02$ \\
dsRNA & 5 & 2 & $2.7 \pm 0.1$ & $7.31 \pm 0.01$ \\
dsRNA & 7 & 7 & $2.5 \pm 0.1$ & $7.27 \pm 0.02$ \\
E. coli LPS & 5 & 2 & $2.5 \pm 0.1$ & $7.25 \pm 0.02$ \\
E. coli LPS & 8 & 7 & $2.4 \pm 0.2$ & $7.24 \pm 0.04$ \\
\hline
\end{tabular}

* Treatment dose of the 3 agonists was $10 \mathrm{mg} /$ fetal lamb. Mean \pm SEM. PAM indicates PAMCysK P $_{4}$, dsRNA, poly I:C dsRNA. 

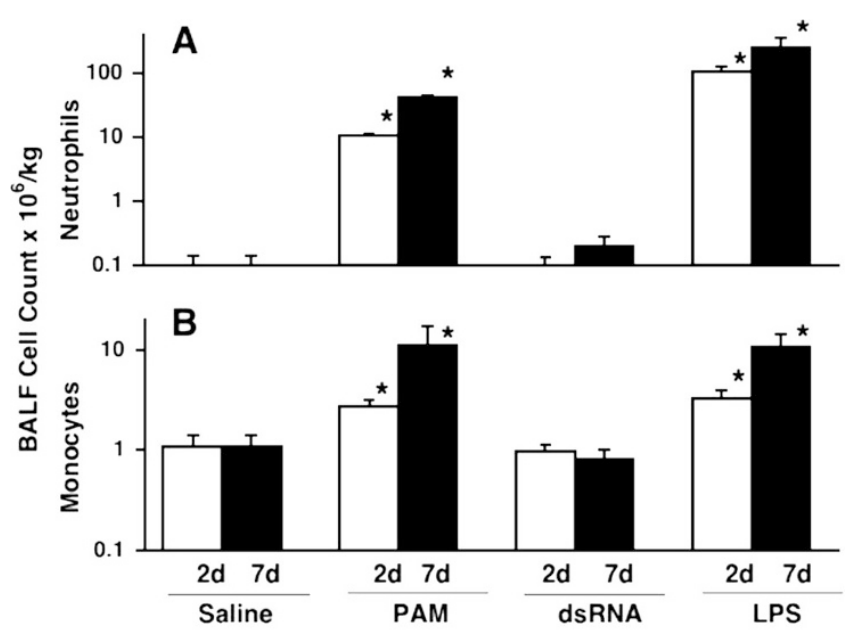

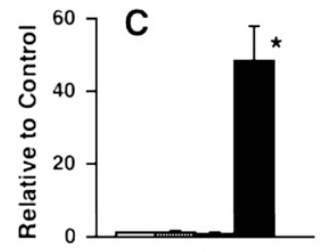

IL-I $\beta$

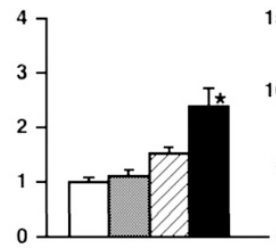

IL-6

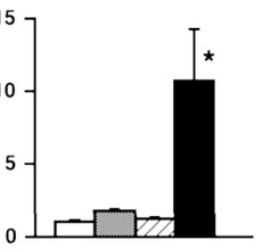

IL-8
Figure 4. Inflammatory cell and cytokine response to TLR agonists. Intraamniotic PAMCysK $_{4}$ (PAM) and E. coli LPS (LPS) caused an increase in (A) neutrophils and $(B)$ monocytes in BALF versus saline controls (white bars). Poly I:C dsRNA (dsRNA) did not increase the inflammatory cells. $(C)$ Cytokine mRNA for IL-1 $\beta$, IL-6, and IL-8 increased in the fetal lung $2 \mathrm{~d}$ after LPS (black bar), but not after $\mathrm{PAMCysK}_{4}$ (PAM) (gray bar), or dsRNA (striped bar). ${ }^{*} p<0.05$ versus saline control.
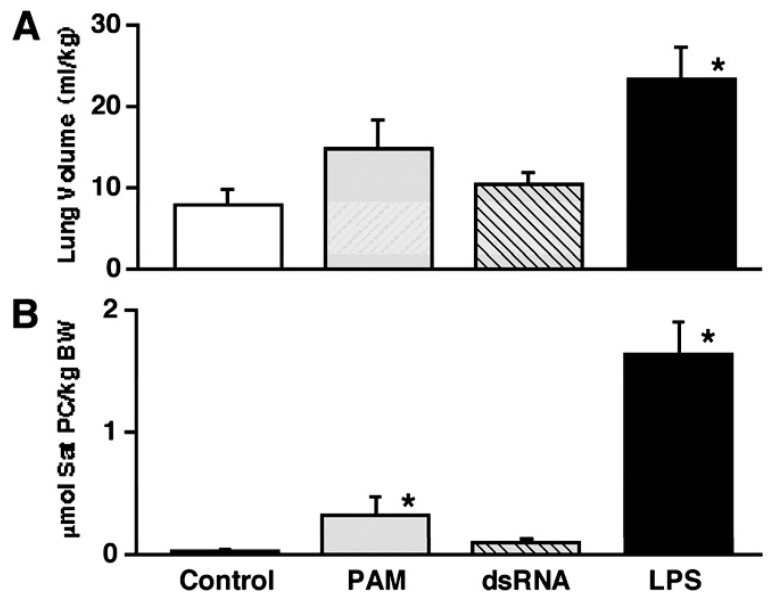

Figure 5. Lung volumes and surfactant $7 \mathrm{~d}$ after intra-amniotic injection of toll-like receptor agonists. (A) Compared with saline controls, LPS increased lung volumes at $40 \mathrm{~cm} \mathrm{H}_{2} \mathrm{O}$ pressure. PAMCysK $\mathrm{K}_{4}$ (PAM) and poly I:C dsRNA (dsRNA) did not increase lung gas volumes. (B) Saturated Phosphatidylcholine (Sat PC) increased after injection with PAMCysK $_{4}$ and LPS. * $p<$ 0.05 versus saline controls.

the mean lung gas volume of $8.1 \pm 1.8 \mathrm{~mL} / \mathrm{kg}$ in the control group. The amount of Sat PC in the BALF was 10 times greater for PAMCysK $_{4}$ animals than for the controls $(p=0.03)$ and 61 times greater in LPS $(p<0.01)$. Intra-amniotic Poly I:C dsRNA did not increase lung gas volumes or surfactant.

Effects of TLR agonists on TLR expression in the fetal lung. Fetal exposure to the TLR4 agonist LPS increased the expression of TLR 2 mRNA at 2 and $7 \mathrm{~d}$, and TLR 4 mRNA at
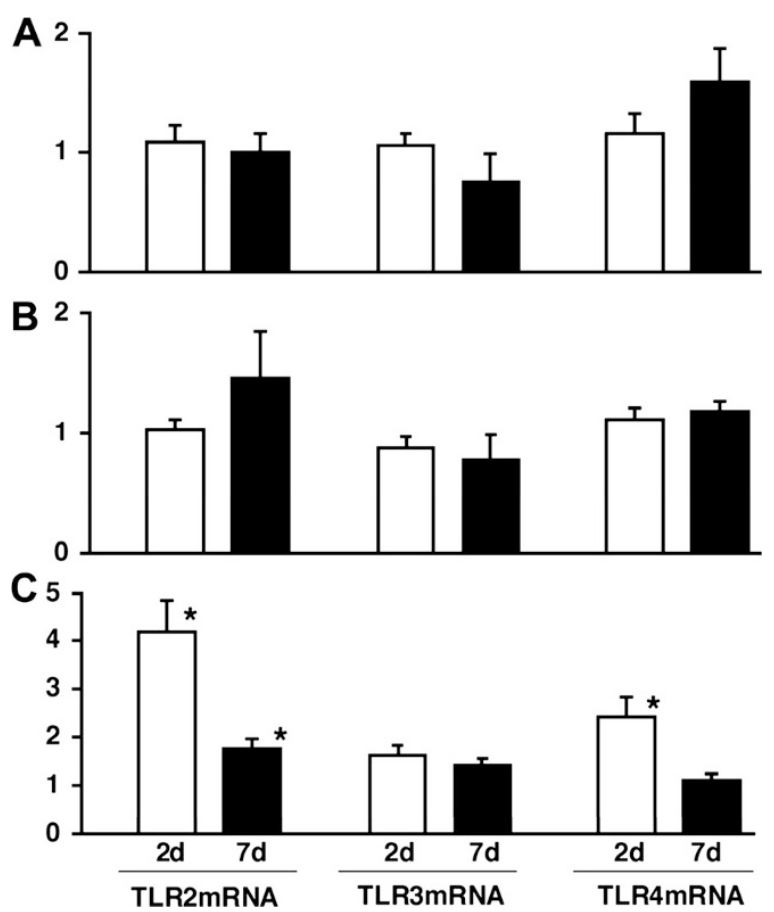

Figure 6. TLR mRNA induction with TLR agonists. TLR mRNAs were determined by RNase protection assay using $\left[{ }^{32} \mathrm{P}\right]$-labeled sheep-specific riboprobes. TLR mRNA values were initially normalized to L32 mRNA (loading control). All values are reported as fold increases compared with control animals, normalized to 1. (A) $\mathrm{PAMCysK}_{4}$ (TLR2 agonist) and (B) poly I:C dsRNA (TLR3 agonist). (C) LPS-induced TLR2 and TLR4 mRNA at $2 \mathrm{~d}$ (white bars), and TLR2 mRNA at $7 \mathrm{~d}$ (black bars). ${ }^{*} p<0.05$ versus saline controls.

$2 \mathrm{~d}$ (Fig. 6). In contrast, intra-amniotic exposures of fetuses to TLR2 or TLR3 agonists did not change the expression of TLR2, 3, or 4 mRNA at 2 or $7 \mathrm{~d}$.

\section{DISCUSSION}

Innate immunity is the essential first defense response to pathogen invasion. A response is initiated in the adult lung by the interactions of soluble recognition factors such as LPS binding protein, soluble CD14, and the surfactant proteins A and $\mathrm{D}$, which bind the pathogen product and modulate the TLR4 signaling at the cell membrane (23). In the mature lung, TLRs and other cofactors expressed on alveolar macrophages, the pulmonary epithelium, and other lung cells signal effector pathways to induce and release multiple components of the primary inflammatory response that include cytokines and acute phase reactants. The complex recognition, signaling, and response pathways have been minimally studied in the fetus, which is generally considered to be immune naïve, to have immature immune responses, and to have essentially no alveolar macrophages $(8,24)$.

We cloned TLR2, 3, and 4 and found that these DNA sequences for the ovine TLRs are similar to the bovine and have $82-88 \%$ homology with the human TLRs, as others have reported (25). The fetus responds consistently to the intraamniotic TLR4 agonist with lung inflammation and induced lung maturation. The responses to $10 \mathrm{mg}$ of the TLR2 agonist $\mathrm{PAMCysK}_{4}$ were less consistent and there was no response to 
a TLR3 agonist. LPS exposure induced expression of TLR2 and TLR4 mRNA at $2 \mathrm{~d}$, a response that did not persist for TLR4 at $7 \mathrm{~d}$. PAMCysK 4 did not increase TLR2 or TLR4 mRNA. The number of inflammatory cells in the BAL of the PAMCysK $_{4}$ animals was 10 -fold lower than with LPS. The inconsistent results in $\mathrm{PAMCysK}_{4}$-exposed lambs with increased inflammatory cells but no increase in cytokine mRNA may be because of the timing of the sampling, whereas IA LPS-induced cytokine expression was the highest at $2 \mathrm{~d}$, $\mathrm{PAMCysK}_{4}$ may induce earlier expression of cytokine mRNA, as we noted previously for IL-1 (16). Alternately, $\mathrm{PAMCysK}_{4}$ may induce other cytokines that were not measured. These experiments showed that TLR2, 3, and 4 mRNAs are expressed in fetal ovine lung and the TLR agonists induce different fetal inflammatory responses.

TLR2 and TLR4 mRNA expression patterns in the fetal ovine lung were different. TLR4 was expressed at baseline throughout the lung parenchyma in control animals in multiple cell types. LPS exposure induced increased diffuse expression in multiple cell types in the lung. Similar diffuse localization has been shown in the adult human lung $(23,26,27)$. The resolution of in situ hybridization does not allow for localization of the signal to specific cells. In contrast, TLR2 was expressed at low levels in lung parenchyma in control animals. LPS exposure predominantly induced TLR 2 mRNA in inflammatory cells. The expression of TLR 4 in the inflammatory cells did not increase as strikingly as was seen with TLR2. The increased TLR2 mRNA after LPS exposure was probably largely because of migrating inflammatory cells, whereas TLR4 mRNA increase came from multiple cell types in the lung parenchyma. A difference between TLR expression in the lung has also been seen in the adult horse, where TLR4 but not TLR2 was detected in normal horse lungs, but both receptors were induced by LPS (28).

TLR2 and TLR4 expression increases throughout development in multiple species. In mice, TLR2 and TLR4 mRNA levels are very low in the fetal lung at early gestation (embryonic day 14) and increase eightfold from pseudoglandular to saccular stage in late mouse lung development (10). A similar developmental pattern is seen in human peripheral blood, with preterm infants having less TLR4 on systemic monocytes than do term infants, and adult human monocytes contain more TLR4 than either the term or preterm (29). The decreased levels of TLR4 in preterm monocytes is associated with less cytokine production in humans (29). In sheep, we find large increases in TLR2 and TLR4 from the fetal lung to the adult lung, although no large increase in TLR3 was detected.

In contrast, to TLR 2 and TLR4 mRNA expression, TLR3 mRNA expression did not change throughout gestation and adult levels were not significantly increased compared with fetal/newborn expression. We have previously shown that adult ovine monocytes respond to dsRNA, whereas fetal monocytes do not produce $\mathrm{H}_{2} \mathrm{O}_{2}$ when challenged with dsRNA (18). The responsiveness of adult monocytes to a TLR3 agonist with similar receptor mRNA expression compared with the fetuses suggests that the TLR3 responses may be modulated by a post-transcriptional mechanism. Unfortunately, attempts at TLR3 mRNA cellular localization were unsuccessful, proba- bly because of low fetal TLR3 mRNA expression. Adult mouse macrophages induce TLR3 expression in response to LPS, whereas human cells do not show a similar increase (30). TLR3 is the only toll-like receptor that does not correlate to reperfusion injury in adult human lung transplant tissues (31).

Our results demonstrate clear differences in fetal lung responses between the TLR agonists at a dose of $10 \mathrm{mg}$. We previously described the dose-responses to intra-amniotic LPS. The responses of the fetal lung to doses of 4-100 mg LPS are similar to the $10 \mathrm{mg}$ reported here, and doses lower than $4 \mathrm{mg}$ cause less lung inflammation and less of an induced lung maturation response $(12,13)$. Similarly, intra-amniotic injection of $150 \mu \mathrm{g} \mathrm{IL}-1 \alpha$ causes intense lung inflammation and striking induction of lung maturation, whereas $50 \mu \mathrm{g}$ causes less inflammation and less induced maturation (20). The responses to IL- $1 \alpha$ occur at a dose that is 100 times less than for the agonists for TLR2 and TLR3 tested here. The responses to IL- $1 \alpha$ and LPS are dose-sensitive and high doses do not blunt the responses. We evaluated the TLR2 and TLR3 agonists at doses of $1 \mathrm{mg}$ and $0.1 \mathrm{mg}$ in preliminary studies and found no inflammation responses. Doses of these potent agonists higher than $10 \mathrm{mg}$ are not practical in this large animal model.

Chorioamnionitis is associated with more than $50 \%$ of preterm deliveries before 30-wk gestation (1). Infants exposed to chorioamnionitis have inflammatory cells and mediators in lung fluid at birth indicating inflammation in the fetal lung $(4,32)$. The exposure of the fetal lung to inflammation correlates with a decreased risk of respiratory distress syndrome (induced lung maturation) and an increased risk of bronchopulmonary dysplasia in ventilated infants $(3,4)$. We have now demonstrated that a TLR2 agonist as well as a TLR4 agonist, but not a TLR3 agonist, can also induce increased surfactant pools and lung volumes. Because the pro-inflammatory agents, such as IL-1, do not seem to cross the lung epithelial barrier, local epithelial TLRs or IL-1R must initiate a cascade of signaling that culminates in the induced lung maturation phenotype. These experiments suggest that the induced lung maturation phenotype can be caused by multiple signaling pathways at the airway epithelium, secondary to influx of neutrophils and inflammatory cells in the fetal lung (33). The mechanisms of how activation and influx of inflammatory cells cause lung maturation remain to be studied.

\section{REFERENCES}

1. Goldenberg RL, Hauth JC, Andrews WW 2000 Intrauterine infection and preterm delivery. N Engl J Med 342:1500-1507

2. Costeloe K, Hennessy E, Gibson AT, Marlow N, Wilkinson AR 2000 The EPICure study: outcomes to discharge from hospital for infants born at the threshold of viability. Pediatrics 106:659-671

3. Andrews WW, Goldenberg RL, Faye-Petersen O, Cliver S, Goepfert AR, Hauth JC 2006 The Alabama Preterm Birth study: polymorphonuclear and mononuclear cell placental infiltrations, other markers of inflammation, and outcomes in 23- to 32-week preterm newborn infants. Am J Obstet Gynecol 195:803-808

4. Watterberg KL, Demers LM, Scott SM, Murphy S 1996 Chorioamnionitis and early lung inflammation in infants in whom bronchopulmonary dysplasia develops. Pediatrics 97:210-215

5. Andrews WW, Goldenberg RL, Hauth JC, Cliver SP, Conner M, Goepfert AR 2005 Endometrial microbial colonization and plasma cell endometritis after spontaneous or indicated preterm versus term delivery. Am J Obstet Gynecol 193:739-745

6. Janssens S, Beyaert R 2003 Role of Toll-like receptors in pathogen recognition. Clin Microbiol Rev 16:637-646 
7. Akira S, Uematsu S, Takeuchi O 2006 Pathogen recognition and innate immunity. Cell 124:783-801

8. Marshall-Clarke S, Reen D, Tasker L, Hassan J 2000 Neonatal immunity: how well has it grown up? Immunol Today 21:35-41

9. Kallapur SG, Willet KE, Jobe AH, Ikegami M, Bachurski CJ 2001 Intra-amniotic endotoxin: chorioamnionitis precedes lung maturation in preterm lambs. Am J Physiol Lung Cell Mol Physiol 280:L527-L536

10. Harju K, Glumoff V, Hallman M 2001 Ontogeny of toll-like receptors Tlr2 and Tlr4 in mice. Pediatr Res 49:81-83

11. Kim YM, Romero R, Chaiworapongsa T, Kim GJ, Kim MR, Kuivaniemi H, Tromp G, Espinoza J, Bujold E, Abrahams VM, Mor G 2004 Toll-like receptor-2 and -4 in the chorioamniotic membranes in spontaneous labor at term and in preterm parturition that are associated with chorioamnionitis. Am J Obstet Gynecol 191:13461355

12. Jobe AH, Newnham JP, Willet KE, Moss TJ, Ervin MG, Padbury JF, Sly PD, Ikegami M 2000 Endotoxin induced lung maturation in preterm lambs is not mediated by cortisol. Am J Respir Crit Care Med 162:1656-1661

13. Kramer BW, Moss TJ, Willet K, Newnham J, Sly P, Kallapur SG, Ikegami M, Jobe A 2001 Dose and time response after intra-amniotic endotoxin in preterm lambs. Am J Respir Crit Care Med 164:982-988

14. Moss TJ, Nitsos I, Ikegami M, Jobe AH, Newnham JP 2005 Experimental intrauterine Ureaplasma infection in sheep. Am J Obstet Gynecol 192:1179-1186

15. Newnham JP, Shub A, Jobe AH, Bird PS, Ikegami M, Nitsos I, Moss TJ 2005 The effects of intra-amniotic injection of periodontopathic lipopolysaccharides in sheep. Am J Obstet Gynecol 193:313-321

16. Sosenko IR, Kallapur SG, Nitsos I, Moss TJ, Newnham JP, Ikegami M, Jobe AH 2006 IL- $1 \alpha$ causes lung inflammation and maturation by direct effects on preterm fetal lamb lungs. Pediatr Res 60:294-298

17. Willet KE, Jobe AH, Ikegami M, Newnham J, Brennan S, Sly PD 2000 Antenatal endotoxin and glucocorticoid effects on lung morphometry in preterm lambs. Pediatr Res 48:782-788

18. Kramer BW, Jobe AH 2005 The clever fetus: responding to inflammation to minimize lung injury. Biol Neonate 88:202-207

19. Moss TJ, Newnham JP, Willet KE, Kramer BW, Jobe AH, Ikegami M 2002 Early gestational intra-amniotic endotoxin: lung function, surfactant, and morphometry. Am J Respir Crit Care Med 165:805-811

20. Willet KE, Kramer BW, Kallapur SG, Ikegami M, Newnham JP, Moss TJ, Sly PD, Jobe AH 2002 Intra-amniotic injection of IL-1 induces inflammation and maturation in fetal sheep lung. Am J Physiol Lung Cell Mol Physiol 282:L411-L420
21. Bachurski CJ, Pryhuber GS, Glasser SW, Kelly SE, Whitsett JA 1995 Tumo necrosis factor-alpha inhibits surfactant protein $\mathrm{C}$ gene transcription. J Biol Chem 270:19402-19407

22. Wert SE, Glasser SW, Korfhagen TR, Whitsett JA 1993 Transcriptional elements from the human SP-C gene direct expression in the primordial respiratory epithelium of transgenic mice. Dev Biol 156:426-443

23. Martin TR, Frevert CW 2005 Innate immunity in the lungs. Proc Am Thorac Soc 2:403-411

24. Kramer BW, Jobe AH, Ikegami M 2003 Monocyte function in preterm, term, and adult sheep. Pediatr Res 54:52-57

25. Menzies M, Ingham A 2006 Identification and expression of Toll-like receptors 1-10 in selected bovine and ovine tissues. Vet Immunol Immunopathol 109:23-30

26. Armstrong L, Medford AR, Uppington KM, Robertson J, Witherden IR, Tetley TD, Millar AB 2004 Expression of functional toll-like receptor-2 and -4 on alveolar epithelial cells. Am J Respir Cell Mol Biol 31:241-245

27. Morris GE, Whyte MK, Martin GF, Jose PJ, Dower SK, Sabroe I 2005 Agonists of Toll-like receptors 2 and 4 activate airway smooth muscle via mononuclear leukocytes. Am J Respir Crit Care Med 171:814-822

28. Singh Suri S, Janardhan KS, Parbhakar O, Caldwell S, Appleyard G, Singh B 2006 Expression of toll-like receptor 4 and 2 in horse lungs. Vet Res 37:541-551

29. Forster-Waldl E, Sadeghi K, Tamandl D, Gerhold B, Hallwirth U, Rohrmeister K, Hayde M, Prusa AR, Herkner K, Boltz-Nitulescu G, Pollak A, Spittler A 2005 Monocyte toll-like receptor 4 expression and LPS-induced cytokine production increase during gestational aging. Pediatr Res 58:121-124

30. Rehli M 2002 Of mice and men: species variations of Toll-like receptor expression Trends Immunol 23:375-378

31. Andrade CF, Kaneda H, Der S, Tsang M, Lodyga M, Chimisso Dos Santos C Keshavjee S, Liu M 2006 Toll-like receptor and cytokine gene expression in the early phase of human lung transplantation. J Heart Lung Transplant 25:1317-1323

32. Viscardi RM, Muhumuza CK, Rodriguez A, Fairchild KD, Sun CC, Gross GW, Campbell AB, Wilson PD, Hester L, Hasday JD 2004 Inflammatory markers in intrauterine and fetal blood and cerebrospinal fluid compartments are associated with adverse pulmonary and neurologic outcomes in preterm infants. Pediatr Res 55:1009-1017

33. Kallapur SG, Moss JT, Newnham JP, Ikegami M, Jobe AH 2005 Recruited inflammatory cells mediate endotoxin-induced lung maturation in preterm fetal lambs. Am J Respir Crit Care Med 172:1315-1321 